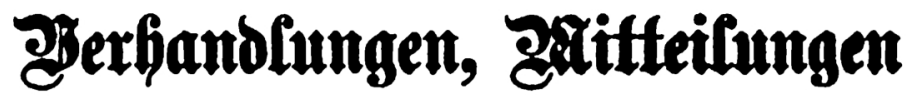 \\ unb \\ Beridhte \\ Des

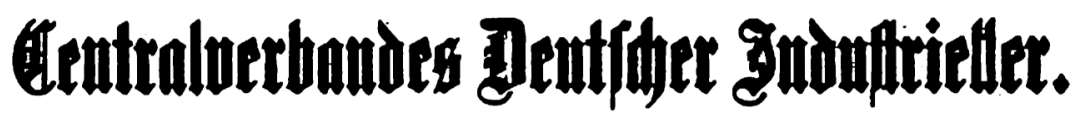 \\ No. 128. \\ Gerausgegeben

\author{
Don

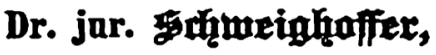 \\ Beneralfetretär des Centralverbandes Deutfąer Induftrieller, \\ Berlin W9, cintftr. 25 (fuggerḩaus).

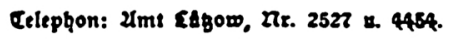

\section{QHEtatuer 1913.}

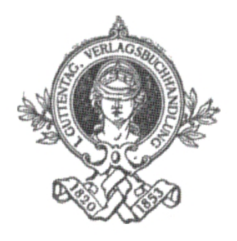

Berlin 1913.

3. Buttentag, Bexlags bughaubluug,

๑. แ. b. 8 . 
